Filozofska fakulteta, Univerza v Ljubljani

meta.lah@ff.uni-lj.si

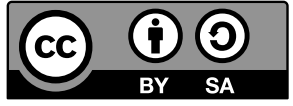

\title{
ITALIJANŠČINA ZA ŠTUDENTE ETNOLOGIJE IN KULTURNE ANTROPOLOGIJE II - ITALIANO PER GLI STUDENTI DI ETNOLOGIA E ANTROPOLOGIA CULTURALE II
}

Kaja Brecelj (2018). Italijanščina za študente etnologije in kulturne antropologije II - Italiano per gli studenti di etnologia e antropologia culturale II. Ljubljana: Znanstvena založba Filozofske fakultete Univerze v Ljubljani. ISBN 978-961-06-0094-7, 149 strani, 16,40 €.

Učbenik Italiano per gli studenti di etnologia e antropologia culturale II obsega 149 strani in je opremljen z avtorskimi ilustracijami Petre Brecelj. Namenjen je študentom, ki z učenjem italijanščine nadaljujejo (raven A2/B1 po Skupnem evropskem jezikovnem okviru).

Učbenik je razdeljen v dvanajst poglavij: Italia, Friuli - Venezia Giulia, Veneto, Trentino - Alto Adige, Piemonte, Lombardia, Liguria, Toscana, Campania, Puglia, Sicilia in Sardegna. V bibliografiji na koncu učbenika so navedeni viri razdeljeni v tri skupine: besedila, prirejena po elektronskih virih, besedila, prirejena po drugih virih in video posnetki.

Avtorica je v vseh enotah uporabila enako zaporedje aktivnosti. Na začetku vsake je del, poimenovan Che cosa sai già! (Kaj že veš), del, namenjen priklicu že znanega in motivaciji za nadaljnje učenje. Sledi Verso il testo, v katerem je predstavljeno besedišče, uporabljeno v enoti (ali uporabno za govorjenje o določeni temi), sledi besedilo z vajo Focus sulla comprensione. Po tem sta predstavljena dela, namenjena usvajanju besedišča in slovnice, Focus sul lessico, Focus sulla grammatica. Večino enot sklene del, naslovljen Ora tocca a te! (Zdaj si ti na vrsti), v katerem mora študent uporabiti besedišče in strukture, ki se jih je poprej naučil v vsaki enoti. V tem delu gre večkrat tudi za projektno delo oz. opravila, saj je avtorica predvidela aktivnosti, ki jih bodo študentje izpeljali v parih ali v skupinah, s pomočjo različnih virov, ki jih bodo našli sami in bodo dopolnili učbeniško gradivo.

Avtorica je učbenik tematsko spretno zgradila tako, da preide od splošnejšega k bolj specifičnemu in od znanega k manj znanemu; v prvi enoti namreč predstavi državo ciljnega jezika, Italijo, nato pa v naslednjih enotah nadaljuje s posameznimi pokrajinami. Učbenik je po temah dobro prilagojen ciljni publiki, študentom etnologije in kulturne antropologije; vključuje namreč besedila, ki jih bodo zanimala ali jim utegnejo priti prav, na primer predstavitev Etnografskega muzeja v mestu Servola, različnih običajev, 
tradicionalnih izdelkov (npr. idrijske čipke), izročil (npr. predstavitev folklorne skupine iz Rezije in rezijskih bajk), redkih poklicev (mlekarice v Trstu) in podobno.

Besedila so primerne dolžine in težavnosti, večinoma prirejena po izvirnih. Zelo pohvalno je, da se je avtorica odločila za taka besedila; dosti lažje bi bilo namreč napisati kratka pedagoška besedila na določene teme, bi pa to bilo hkrati veliko manj smiselno in manj uporabno.

Slovnica je v učbeniku v glavnem obravnavana zelo sistematično (velikokrat s pomočjo različnih tabel) in induktivno, se pravi, da bodo študentje iz predloge sami izpeljali pravilo ali na podlagi besedila dopolnili tabelo (aktivnost, ki služi utrjevanju usvojenih struktur). Tak pristop je vsekakor primeren za študente, ki niso več začetniki; na ta način bodo slovnična poglavja bolj utrdili in se jim bodo zdela bolj smiselna.

Pri obravnavi besedišča je avtorica uporabila različne tipe vaj. Večinoma gre za vaje povezovanja in dopolnjevanja, $\mathrm{s}$ katerimi se išče pomen besed, sopomenke ali protipomenke - v italijanščini ali/in materinščini. Večinoma se vaje nanašajo na že znano besedišče, včasih pa si bodo študentje pomagali s slovarjem ali razlago na spletu.

Omeniti velja tudi avtorske ilustracije Petre Brecelj, ki so prilagojene besedilom in jih ne zasenčijo; so pa zelo dobro dopolnilo k posameznim temam, študentje bodo v njih (npr. v zemljevidih) našli tudi dodatne informacije.

Učbenik Italijanščina za študente etnologije in kulturne antropologije II upošteva smernice sodobnega jezikovnega pouka. Pomembno in pozitivno je, da bodo študentje etnologije in kulturne antropologije uporabljali učbenik, ki je bil napisan posebej zanje in upošteva njihove jezikovne ter kulturne potrebe. Ker je avtorica rojena govorka slovenščine, dobro pozna zagate in težave, na katere pri učenju italijanščine naletijo slovenski govorci in jim je lahko prilagodila razlage in način dela. Želeli bi si, da bi temu sledili še učbeniki za ostale jezikovne ravni. 